(C) Є.С. Сірчак, С.В. Пацкун, 2018

УДК 616.379-008.64:579.835.12]-036-056

\title{
Поширеність факторів ризику виникнення хелікобактер пілорі у хворих із цукровим діабетом II типу
}

\author{
Є.С. Сірчак, С.В. Пацкун
}

Silvika121191@gmail.com

\author{
Ужсгородський національний університет, медичний факультет, кафедра пропедевтики \\ внутрішніх хвороб, Ужсород
}

\section{Реферат}

Вступ. Куріння цигарок викликає різні хвороби, включаючи серцево-судинні захворювання, захворювання легенів та злоякісні новоутворення. Також куріння пов'язано з захворюваннями верхніх відділів шлунковокишкового тракту.

Мета дослідження. Оцінити ступінь поширення факторів ризику інфікування хелікобактер пілорі у хворих на цукровий діабет II типу.

Матеріали та методи. Обстежено 48 пацієнтів, вік яких коливався в межах від 45 до 63 років. У всіх пацієнтів діагностовано цукровий діабет II типу. Також всі обстежені хворі мали скарги з боку органів травлення (печія, відрижка кислим, важкість та біль в епігастрії). Всім пацієнтам проведено фіброгастроезофагодуоденоскопію 3 прицільною біопсією, визначення ступеня обсіменіння НР. Сформовано дві групи пацієнтів в залежності від інфікування хелікобактер пілорі. В I групу увійшло 18 (37,5 \%) осіб, які були хелікобактерпілорі негативними, а другу групу сформовано $з 30$ (62,5\%) хворих- хелікобактерпілорі позитивних з ЦД ІІ типу.

Результати досліджень та їх обговорення. Отримані результати вказують на залежність між ступенем обсіменіння гелікобактер пілорі та кількістю цигарок. Так, високий ступінь обсіменіння (більше 50 бактерій в полі зору) спостерігався у 66,7 \% хворих, котрі курять більше 10 цигарок в день.

Нами було також виявлено достовірну різницю між ступенем обсіменіння НР у пацієнтів ІІ групи та кількістю вживаного алкоголю. Так, серед хворих, які вживали до 50 грам алкоголю на тиждень, 28,6\% мали високий ступінь обсіменіння. Щодо пацієнтів, які вживали більше 50 грам алкоголю на тиждень, у 87,5 \% хворих виявлено високий ступінь обсіменіння.

Тож встановлено достовірну різницю між ступенем обсіменіння у пацієнтів II групи та кількістю вживаної кави. Так, серед хворих, які вживали більше 2 чашок кави щодня, виявлено високий ступінь обсіменіння у $85,0 \%$.

Висновки. У хворих на ЦД ІІ типу спостерігається висока частота інфікування НР (62,5\%). Факторами ризику інфікування гелікобактер пілорі у хворих 3 цукровим діабетом II типу є куріння, вживання алкоголю та надмірне зловживання кавою. Виявлено зв'язок між кількістю викурених цигарок, кількістю випитого алкоголю та кофеїну і ступенем обсіменіння шлунка гелікобактер пілорі.

Ключові слова: цукровий діабет 2 типу, хронічний гастрит, хелікобактер пілорі, фактори ризику

Prevalence of helicobacter pyloririsk factors in patients with diabetes mellitus 2 type

Sirchak E.S., Patskun S.V.

Uzhhorod National University, Uzhhorod

Smoking of cigarettes causes various diseases, including cardiovascular diseases, lung disease and malignant neoplasia. Also, smoking is associated with diseases of the upper gastrointestinal tract.

The purpose of the study is to estimate the prevalence of the helicobacter pylori (HP) risk factors in patients with type 2 diabetes mellitus (DM).

Materials and methods. We examined 48 patients whose age ranged from 45 to 63 years. All types of patients have DM 2 type. Also, all examined patients had complaints of the digestive system (liver, bloating, acidity, and pain in the epigastrium). All patients undergo fibrogastroduodenoscopy with a target biopsy, determining the degree of HP seeding. Two groups of patients were formed, depending on the presence of the helicobacter pylori. Group I included $18(37.5 \%)$ persons who were HP negative, and the II group consisted of 30 (62.5\%) patients- HP positive with type 2 DM.

Results. The obtained results indicate the relationship between the degree of HP seeding and the number of cigarettes. Thus, a high degree of seeding (more than 50 bacteria in the field of vision) is observed in $66.7 \%$ of patients, who smokes more than 10 cigarettes per day. We also found a significant difference between the degree of HP seeding in group II patients and the amount of alcohol consumed. So, among patients who consumed up to 50 grams of alcohol per week, $28.6 \%$ had a high degree of seeding. As for patients who consumed more than 50 grams of alcohol per week, $87.5 \%$ of patients showed a high degree of seeding.There is also a significant difference between the degree of seeding in group II patients and the amount of coffee consumed. So, among patients who consumed more than 2 cups of coffee every day, a high degree of seeding is detected in $85.0 \%$.

Conclusion.In patients with type 2 DM, a high prevalence of HP $(62.5 \%)$ is observed. The risk factors for HP infection in patients with type $2 \mathrm{DM}$ are smoking, alcohol and excessive coffee consumption. The connection between the number of cigarettes, the amount of alcohol and caffeine, and the degree of stomach seeding by HP have been observed.

Key words: diabetes mellitus type 2, chronic gastritis, helicobacter pylori, risk factors 
Вступ. Куріння цигарок викликає різні хвороби, включаючи серцево-судинні захворювання, захворювання легенів та злоякісні новоутворення. Також куріння пов'язано з захворюваннями верхніх відділів шлунково-кишкового тракту, в тому числі виразкоою хворобою [1].

Ефект від куріння цигарок на оновлення клітин в шлунково-кишковому тракті був переглянутий низкою досліджень, які показують, що тютюновий дим та його активні речовини не тільки гальмують проліферацію клітин слизової, але також викликають апоптоз клітин під час загоєння виразок [2,3].

Куріння цигарок може викликати патогенні та канцерогенні процеси в ШКТ. Це може призвести до важкого хронічного запалення, а згодом до розвитку раку на ділянках запалення. Клінічні та експериментальні дані також показали, що куріння $є$ основним фактором ризику індукції запальних захворювань, таких як виразки та хвороба Крона. Цигарковий дим та його активні речовини ускладнюють основну структуру шлунково-кишкового тракту через індукцію клітинного апоптозу та гальмування оновлення клітин слизової оболонки. Цигарковий дим також перешкоджає захисним механізмам травного тракту шляхом зменшення кровотоку в слизовій оболонці та модуляції імунної системи слизової оболонки. Крім того, цигарковий дим також перешкоджає синтезу та вивільненню епідермального фактора росту та поліамінів, а отже - секреції слизу, яка відіграє важливу роль у захисті цілісності слизової оболонки. Хронічне запалення, викликане дією цигаркового диму, сприяє виділенню різних запальних компонентів, включаючи цитокіни, фактор некрозу пухлин$\alpha$, інтерлейкін-1 та інтерлейкін-6, а також хемокіни - ріст-регулюючий онкоген $\alpha$ (CXCL1) і ангіогенний (CXCL8). Ці запальні компоненти здатні сприяти росту, адгезії та інвазії пухлини. Крім того, ці медіатори також викликають ангіогенез та імунне пригнічення в мікросередовищі пухлини. Поряд 3 індукцією хронічного запалення цигарковий дим та його активні інгредієнти можуть безпосередньо активувати нікотинові ацетилхолінові рецептори і утворювати додатковий ДНК продукт реакції, щоб ініціювати пухлиногенез у ШКТ [4,5].

Існує зворотне співвідношення між споживанням алкоголю та інфекцією Н. pylori. Поширеність H.pylori була меншою зі збільшенням тривалості споживання алкоголю [6,7].

Оскільки було виявлено, що алкоголь має прямий некротичний ефект і може сприяти окислювальному стресу в клітинах слизової оболонки шлунка, індукція клітин Пенета може бути захисним механізмом, спрямованим на відновлення ослабленого епітеліального захисту [8,9].

Існуючі дані дозволяють припустити, що хронічне вживання алкоголю може впливати на клі-
тиниПенета, що згодом може змінити вроджений антимікробний захист шлунка [10].

Мета дослідження. Оцінити ступінь поширення факторів ризику інфікування хелікобактер пілоріу хворих на цукровий діабет II типу.

Матеріали та методи. На базі ендокринологічного та гастроентерологічного відділення ЗОКЛ імені А. Новака обстежено 48 пацієнтів, вік яких коливався в межах від 45 до 63 років. Дане дослідження проводилося за участі $26(54,2 \%)$ жінок та 22 (45,8\%) чоловіків. У всіх пацієнтів діагностовано цукровий діабет II типу. Також всі обстежені хворі мали скарги з боку органів травлення (печія, відрижка кислим, важкість та біль в епігастрії). Діагноз ЦД ІІ типу встановлено згідно з рекомендаціями International Diabetes Federation (IDF, 2005 p.), тобто визначення рівня глюкози у сироватці крові натще і через 2 години після прийому, що проводилося за допомогою глюкозооксидантного методу. Ступінь тяжкості діабету оцінювали за рівнем глікозильованого гемоглобіну (HbAlc, \%), який визначали за допомогою хромогенного аналізу на апараті Sysmex 560 (Японія) із використанням реактивів фірми Siemens. Всім пацієнтам проведено фіброгастроезофагодуоденоскопію (ФГДС, 3 використанням ендоскопу «PentaxFG-29V», Японія) 3 прицільною біопсією (було взято 5 зразків матеріалу для біопсії з слизової оболонки шлунка). Дані зразки були передані для подальшого гістологічного дослідження, а також для визначення обсіменіння НР-інфекцією. Біоптати фіксували в формаліні, а далі заливали парафіном. Зрізи забарвлювали по Романовському - Гімзе. Провели визначення ступеня обсіменіння: 0 - бактерії в препараті відсутні, - низький ступінь обсіменіння (до 20 мікробних тіл в полі зору), - середній ступінь обсіменіння (від 20 до 50 мікробних тіл в полі зору), 3 - високий ступінь обсіменіння (більше 50 мікробних тіл в полі зору).Також НР визначали використовуючи швидкий уреазний тест (CLOtest) та НР за допомогою С13 - дихального уреазного тесту (С13-ДУТ) (IZINTA, Угорщина).

Критеріями включення пацієнтів до даного дослідження були:

- пацієнти 3 підтвердженим діагнозом ЦД II типу з НР - інфекцією;

- пацієнти 3 підтвердженим діагнозом ЦД II типу з негативною НР - інфекцією.

Критеріями виключення пацієнтів 3 даного дослідження були:

- пацієнти з ЦД I типу;

- пацієнт, який отримував антигелікобактерну терапію.

Всі хворі були розділені на дві групи в залежності від інфікування хелікобактер пілорі. В I групу увійшло 18 (37,5 \%) осіб, які були хелікобактерпілорі негативними, а другу групу сформовано 3 $30(62,5 \%)$ хворих - хелікобактер пілорі позитивних з ЦД II типу. 
Вік та стать обстежених пацієнтів

\begin{tabular}{|l|l|l|}
\hline & $\begin{array}{l}\text { I група хелікобактер } \\
\text { пілорі негативні } \\
\text { хворі на Цд II типу } \\
\mathrm{n}=18\end{array}$ & $\begin{array}{l}\text { II група хелікобактер } \\
\text { пілорі позитивні } \\
\text { хворі на Цд II типу } \\
\mathrm{n}=30\end{array}$ \\
\hline Середній вік (роки) & $48,79 \pm 0,85$ року & $61,20 \pm 0,69$ року \\
\hline $\begin{array}{l}\text { Стать }(\mathrm{p}=0,02) \\
\text { Жіноча }\end{array}$ & $13(72,2 \%)$ & $11(36,7 \%)$ \\
\hline Чоловіча & $5(27,8 \%)$ & $19(63,3 \%)$ \\
\hline
\end{tabular}

Для виявлення факторів обтяженого перебігу ЦД II типу та ризику інфікування НР всім хворим проведено детальне анкетування. Під час опитування та анкетування акцент робився на виявленні таких шкідливих звичок, як куріння, вживання алкоголю, а також вживання кави.

Усі дослідження проведені за згодою хворих, а їх методика відповідала гельсінській декларації 1975 року та іï̈ перегляду 1983 року.

Наукове дослідження є фрагментом ДБ теми №851 «Механізми формування ускладнень при захворюваннях печінки та ПЗ, методи їх лікування та профілактики» (номер державної реєстрації 0115U001103).

Аналіз і обробка результатів обстеження хворих здійснювалися за допомогою комп'ютерної програми STATISTICA 6.0 (фірми StatSoftInc, США).

Результати досліджень та їх обговорення. Всі обстежені нами хворі на ЦД II типу мали скарги 3 боку органів травлення, а саме: відрижку, важкість та дискомфорт у верхніх відділах живота (табл. 2).

Таблиця 2

Частота клінічних проявів ураження верхніх відділів ШКТ у обстежених хворих на ЦД II типу

\begin{tabular}{|l|c|c|}
\hline \multicolumn{1}{|c|}{ Клінічні прояви } & $\begin{array}{c}\text { I група (HP -) } \\
\mathrm{n}=18\end{array}$ & $\begin{array}{c}\text { I група (HP +) } \\
\mathrm{n}=30\end{array}$ \\
\hline Відрижка кислим & $11(61,1 \%)$ & $22(73,3 \%)^{*}$ \\
\hline Печія & $15(83,3 \%)$ & $26(86,7 \%)$ \\
\hline Нудота & $7(38,9 \%)$ & $12(40,0 \%)$ \\
\hline Важкість в епігастрії & $10(55,6 \%)$ & $18(60,0 \%)$ \\
\hline Біль в епігастрії & $7(38,9 \%)$ & $12(40,0 \%)$ \\
\hline
\end{tabular}

Примітка: різниця між показниками I та II груп достовірна: * $(\mathrm{p}<0,05)$.

Отже, як наведено у таблиці 2, клінічні прояви ураження верхніх відділів ШКТ, а саме: відрижка кислим, печія, нудота, важкість та біль в епігастрії більш виражені у НР-інфікованих хворих на ЦД ІІ типу.
Результати ендоскопічного дослідження верхніх відділів шлунково-кишкового тракту також вказують на більш часте ураження у хворих саме II групи (НР+ пацієнти на ЦД II типу) (табл. 3).

Таблиця 3

Результати ФГДС обстеження у хворих на ЦД II типу

\begin{tabular}{|l|c|c|}
\hline \multicolumn{1}{|c|}{ Результати } & I група $\mathrm{n}=18$ & II група $\mathrm{n}=30$ \\
\hline ГЕРХ & $4(22,2 \%)$ & $11(36,7 \%)$ \\
\hline Рефлюкс - езофагіт & $4(22,2 \%)$ & $11(36,7 \%)$ \\
\hline Хронічний гастрит & $8(44,4 \%)$ & $17(56,7 \%)$ \\
\hline Хронічний дуоденіт & $6(33,3 \%)$ & $10(33,3 \%)$ \\
\hline $\begin{array}{l}\text { Виразкова хвороба дванадцятипалої } \\
\text { кишки }\end{array}$ & - & $3(10 \%)$ \\
\hline
\end{tabular}

Після проведеного дослідження встановлено, що 30 хворих на ЦД ІІ типу є НР-позитивними (за результатами як швидкісного уреазного тесту, так і С13 - дихального уреазного тесту та гістологічного дослідження). У НР-позитивних хворих також нами проведено визначення ступеня обсіменіння СОШ НР за методикою Л.І. Аруїна та спів- авторів. При цьому встановлено, що у 18(60,0\%) хворих - високий ступінь обсіменіння НР $(+++)$; у $9(30,0 \%)$ хворих встановлено ступінь обсіменіння середній $(++)$; а у $3(10,0 \%)$ хворих - низький ступінь обсіменіння НР (+).

При обробці результатів анкетування на виявлення факторів ризику отримано такі результати, а 
саме в I групі $13(72,2 \%)$ пацієнтів не курять, $6(20,0 \%)$ хворих є пасивними курцями, а 2 (11,1\%)

- курять; у II групі: 3 (10,0\%) осіб не палять, 6
(20\%0 є пасивними курцями, а 21 (70,0\%) курять. Тобто виявлено достовірну різницю між двома групами пацієнтів щодо куріння $(\mathrm{p}=0,01)$.

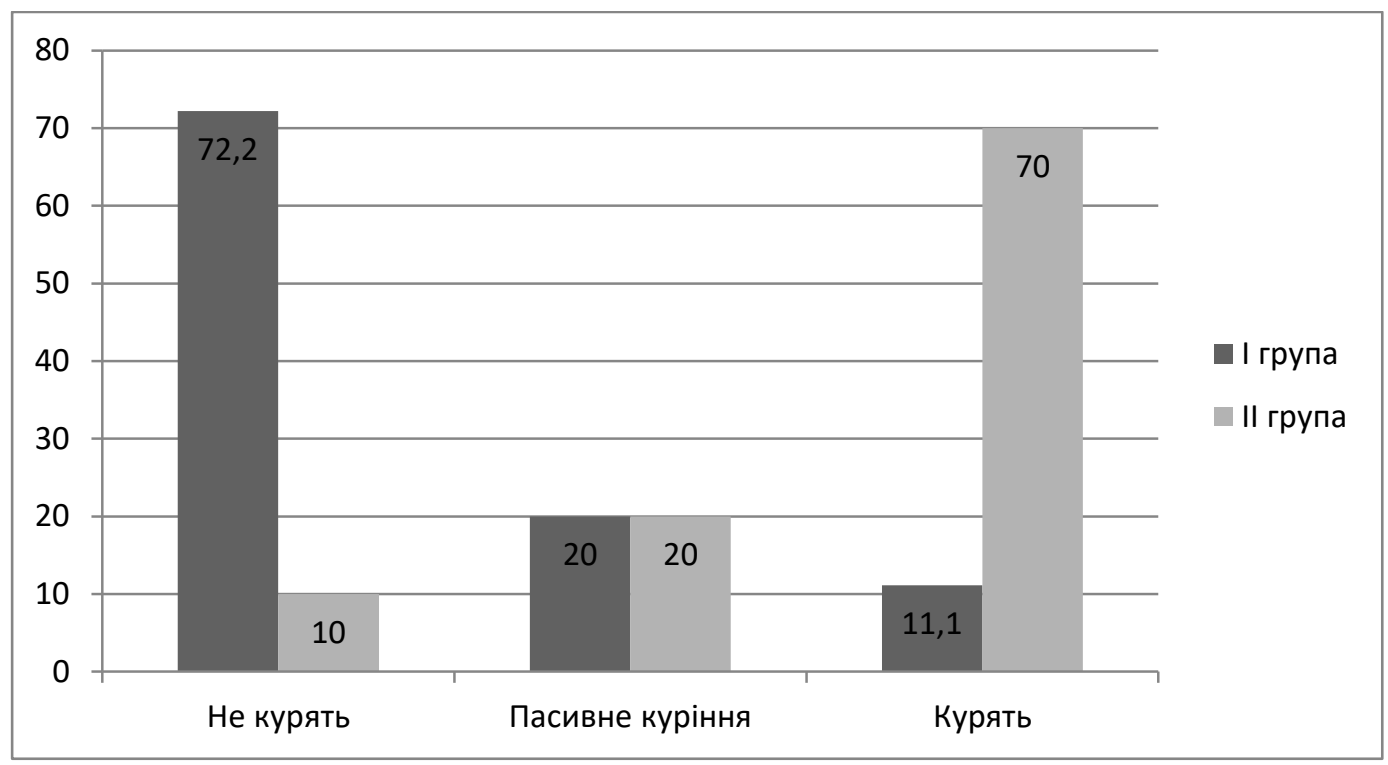

Рис. 1. Розподіл обстежених пацієнтів за наявністю шкідливої звички - куріння (\%)

При подальшому обстеженні пацієнтів на ЦД II типу отримано достовірну різницю між двома групами за таким параметром, як вживана кава. В залежності від кількості вживаної кави хворих розділено таким чином: пацієнти, які взагалі не вживають каву, хворі, вживають $\leq 2$ чашки, а також - $>2$-ох щодня. Отже, в I групі ми виявили такий розподіл за кількістю випитої кави протягом дня: 7 $(38,9 \%)$ пацієнтів взагалі не вживають каву, 11 $(61,1 \%)$ хворих $-\leq 2$-і чашки. У II групі отримано такі результати: 10 (33,3\%) вживають $\leq 2$ чашки, а $20(66,7 \%)$ хворих - більше 2-ох чашок $(\mathrm{p}=0,001)$.

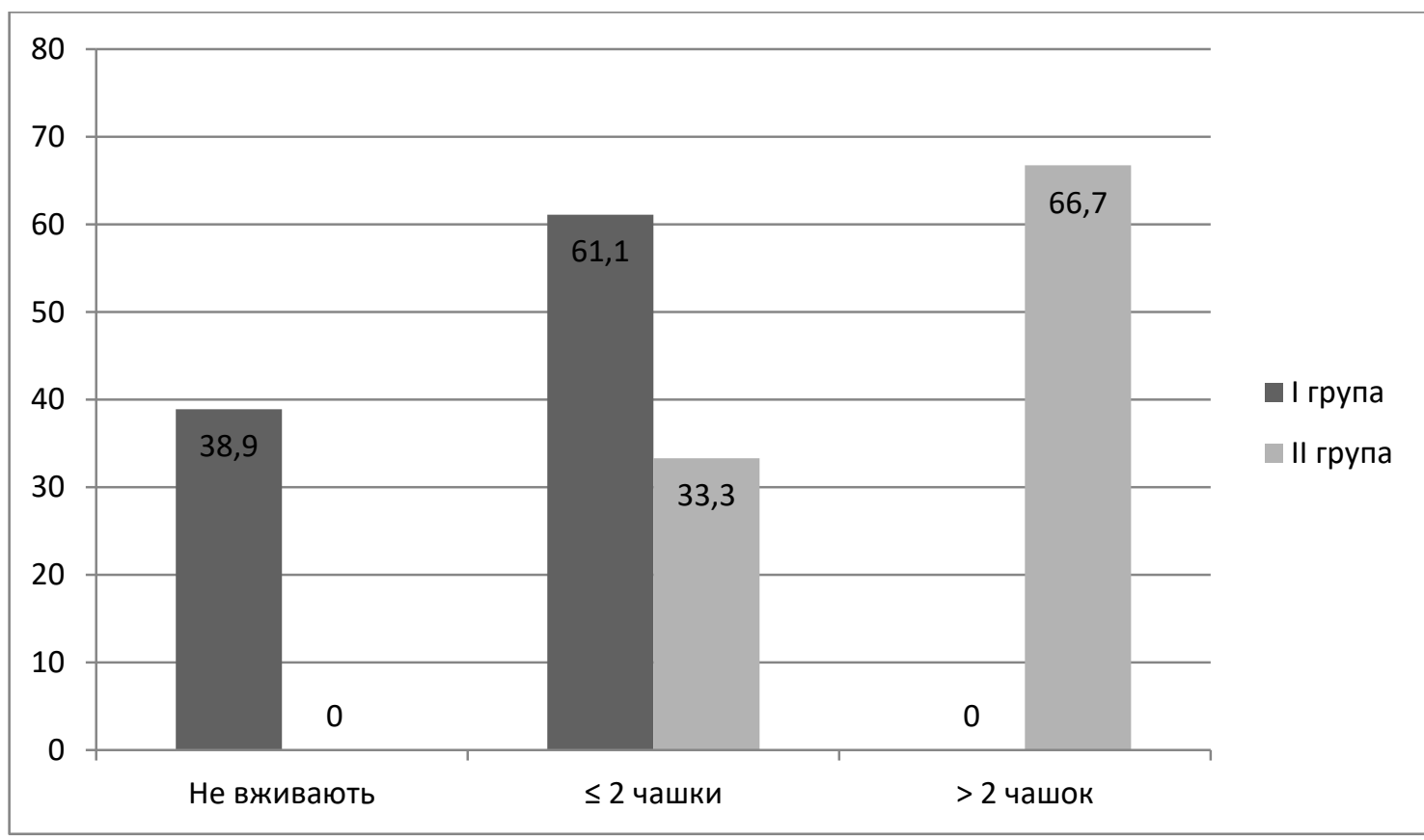

Рис. 2. Розподіл обстежених пацієнтів за кількістю вживаної кави щодня (\%)

Наступний оцінюваний параметр, за яким проводилося порівняння двох груп хворих між собою, було вживання алкоголю. Відповідно до цього всіх обстежених поділено на 3 підгрупи, а саме: особи, які не вживають алкоголь, випивають до 50 грамів на тиждень та більше 50 грамів на тиждень. Виявлено достовірну закономірність, серед пацієнтів I групи: 4 (22,2\%) осіб не вживають алкогольні 
напої, 10 (55,6\%) - випивають до 50 грам щотижня і $4(22,2 \%)$ - більше 50 грам на тиждень. В II групі обстежених встановлено, що всі хворі вживають алкоголь, а саме 14 (46,7\%) хворих вживають до 50 грамів алкоголю щотижня та $16(53,3 \%)$ - більше 50 грамів на тиждень. $(\mathrm{p}=0,003)$.

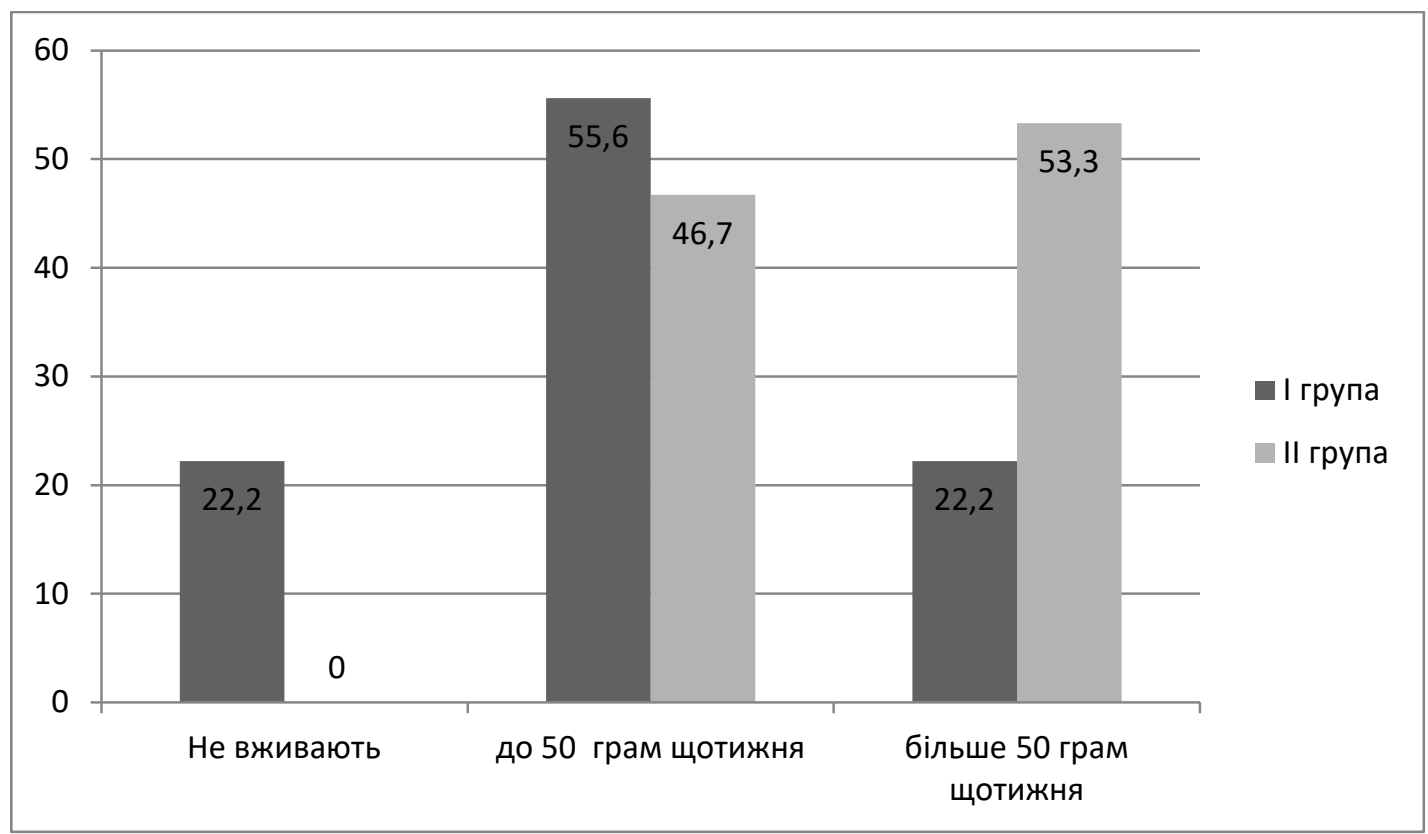

Рис. 3. Розподіл пацієнтів двох груп за кількістю вживаного алкоголю щотижня (\%)

Нами було проведено дослідження зв'язків між ступенем обсіменіння гелікобактер пілорі шлунку та кількістю викурених цигарок, вживаного алкоголю та випитої кави.

Серед обстежених пацієнтів II групи 70\% (21 особа) пацієнтів є курцями: $18(85,7 \%)$ пацієнтів палять $\geq 10$ цигарок щодня, 3 (14,3 \%) хворих курять від 5 до 10 цигарок щодня. Отримані результати вказують на залежність між ступенем обсіменіння гелікобактер пілорі та кількістю викурених цигарок.
У пацієнтів, які курять від 5 до 10 цигарок щодня спостерігалися такі ступені обсіменіння, а саме: 2 (66,7\%) осіб з легким ступенем обсіменіння (до 20 бактерій в полі зору), 1 (33,3\%) - середній ступінь (від 20 до 50 бактерій в полі зору). Серед хворих, котрі курять $\geq 10$ цигарок вдень $1(5,6 \%)$ мали низький ступінь обсіменіння, 5 (27,7\%) хворих - середній ступінь обсіменіння та $12(66,7 \%)$ - високий ступінь обсіменіння гелікобактерпілорі (більше 50 бактерій в полі зору). (p=0,04).

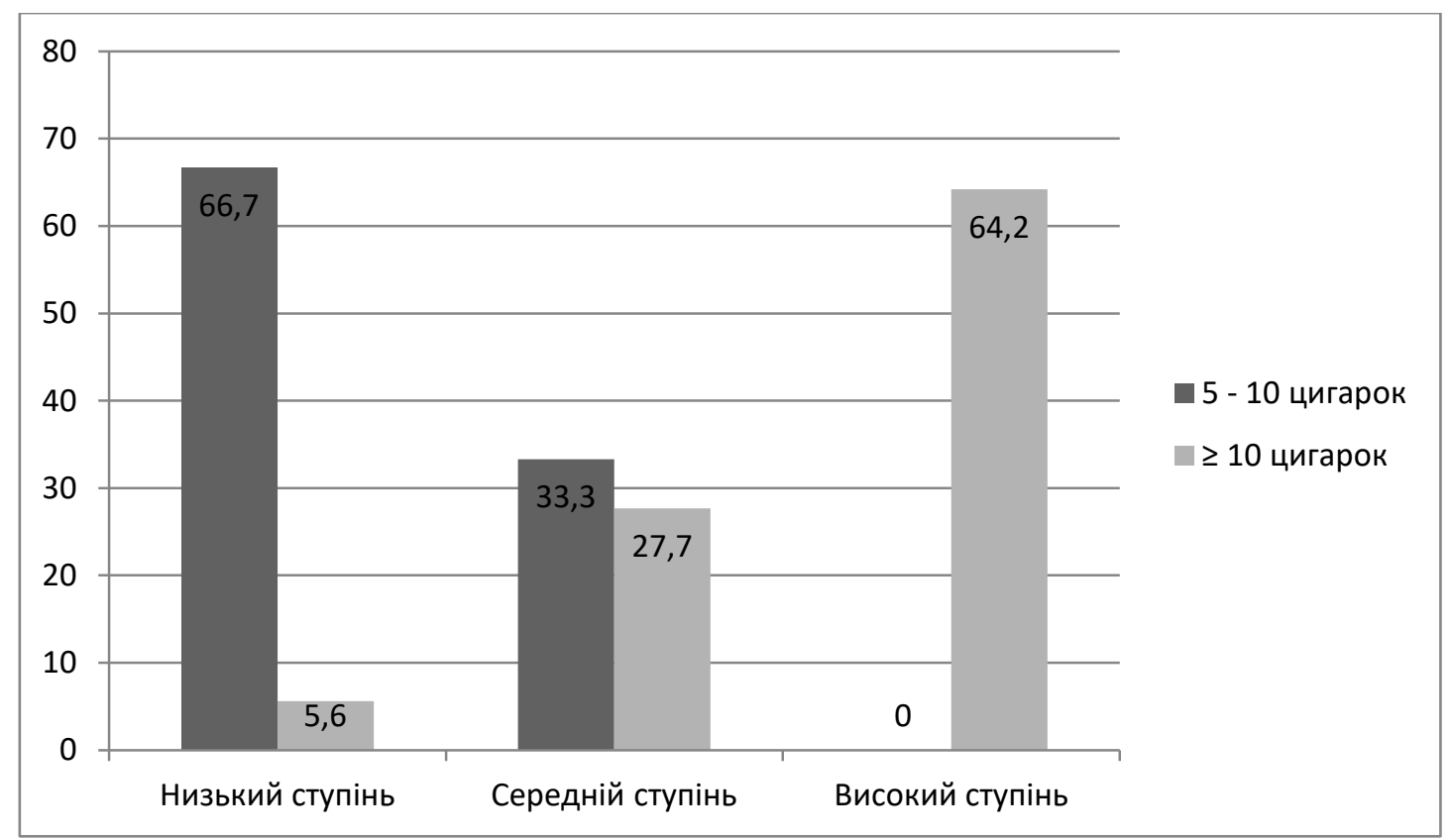

Рис. 4. Залежність між ступенем обсіменіння шлунка гелікобактер пілорі та кількістю викурених цигарок (\%) 
Нами було також виявлено достовірну різницю між ступенем обсіменіння НР у пацієнтів II групи та кількістю вживаного алкоголю. Так, серед хворих, які вживали до 50 грамів алкоголю на тиждень, 4 (28,6\%) осіб мали низький ступінь обсіменіння, 6
(42,8\%) - середній ступінь обсіменіння та 4 (28,6\%)високий ступінь. Наступні результати отримані у пацієнтів, котрі вживали більше 50 грамів алкоголю на тиждень, а саме: 2 (12,5\%) - середній ступінь обсіменіння і $14(87,5 \%)$ - високий $(\mathrm{p}=0,009)$.

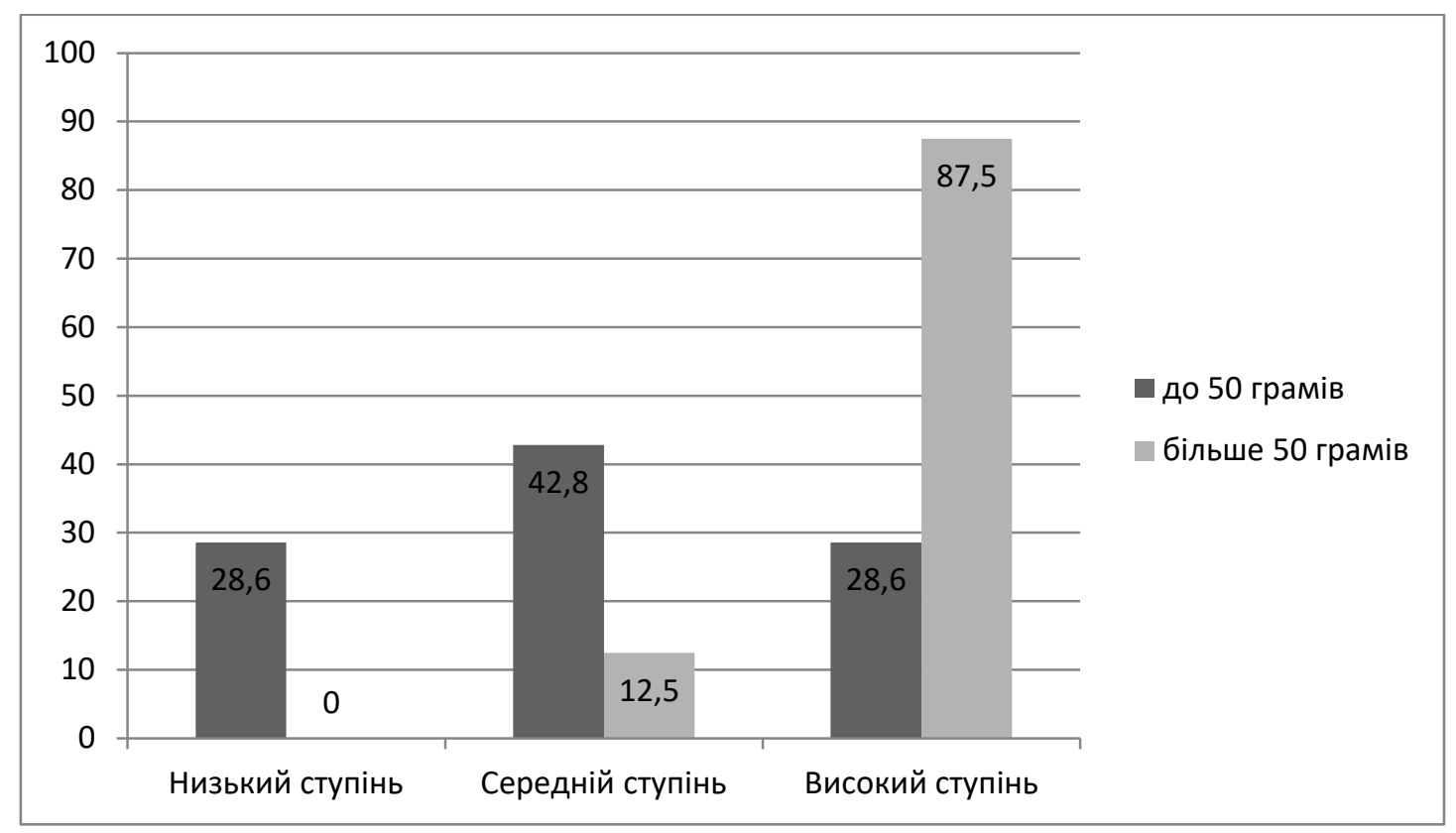

Рис. 5. Залежність між ступенем обсіменіння шлунка гелікобактер пілорі та кількістю випитого алкоголю на тиждень (\%)

Тож встановлено достовірну різницю між ступенем обсіменіння у пацієнтів II групи та кількістю вживаної кави. Так, серед хворих, які вживали $\leq 2$ чашок кави щодня, $3(30,0 \%)$ осіб мали низький ступінь обсіменіння, 5 (50,0\%) - середній ступінь обсіменіння та $2(20,0 \%)$ - високий ступінь. Наступні результати отримані у пацієнтів, котрі вживали більше 2 чашок кави щодня, а саме: 3 (15,0\%) - середній ступінь обсіменіння і 17 (85,0 \%) - високий $(\mathrm{p}=0,002)$.

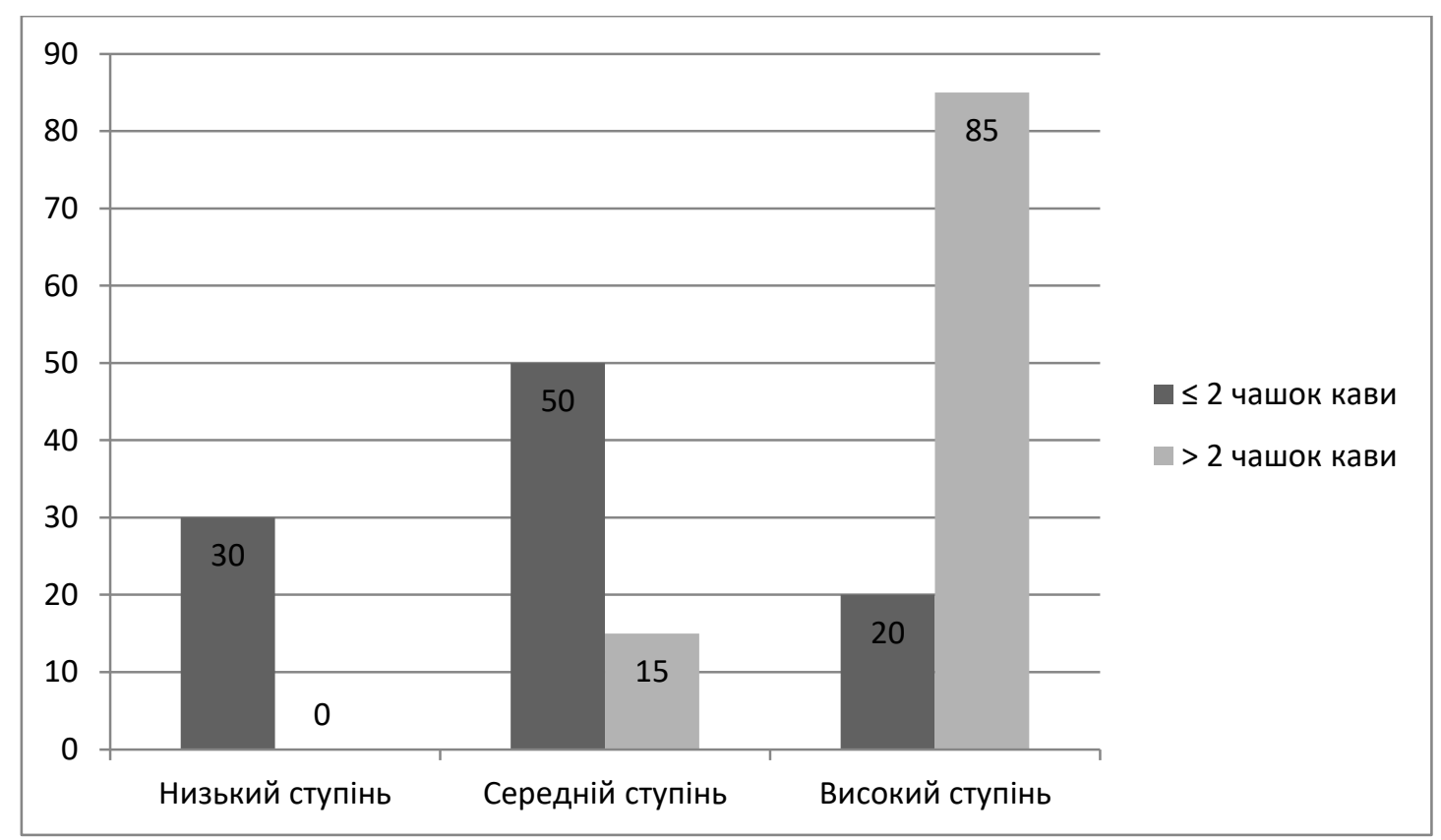

Рис. 6. Залежність між ступенем обсіменіння шлунка гелікобактер пілорі та кількістю випитої кави щодня (\%) 
Отже, хворі на ЦД II типу є групою ризику щодо інфікування НР-інфекцією. Такі шкідливі звички, як зловживання алкоголем, кавою, тютюнокуріння сприяють інфікуванню НР даних пацієнтів. 3 одного боку - НР-інфекція, з іншого - автономна діабетична полінейропатія $\epsilon$ провідними етіопатогенетичними факторами ураження верхніх відділів ШКТ у хворих на ЦД II типу. Як показують результати наших досліджень, наявність вищевказаних негативних факторів сприяє більш швидкому прогресуванню та формуванню більш виражених змін 3 боку езофагогастро-дуоденальної зони. Відмова від шкідливих звичок у поєднанні із ерадикацією НР-інфекції може лежати в основі профілактики прогресування ураження верхніх відділів ШКТ у хворих на ЦД ІІ типу.

Висновки. 1. У хворих на ЦД ІІ типу спостерігається висока частота інфікування НР (62,5\%).

2. Факторами ризику інфікування гелікобактер пілорі у хворих з цукровим діабетом II типу є куріння, вживання алкоголю та надмірне зловживання кавою.

3. Виявлено зв'язок між кількістю викурених цигарок, кількістю випитого алкоголю та кофеїну, і ступенем обсіменіння шлунка гелікобактер пілоpi, a саме: підвищення ступеня обсіменіння слизової оболонки шлунка НР залежно від збільшення шкідливих звичок у хворих на ЦД ІІ типу.

Інформація про конфлікт інтересів. Автори заявляють про відсутність конфлікту інтересів при виконанні наукового дослідження та підготовці даної статті.

Інформація про фінансування. Автори гарантують, що вони не отримували жодних винагород в будь-якій формі, здатних вплинути на результати роботи.

Особистий внесок кожного автора у виконання роботи:

Сірчак Є.С. - управління даними, концепція та дизайн дослідження,інтерпретація даних, критичний перегляд рукопису;

Пацкун С.В. - складання рукопису, збір даних та проведення дослідження.

\section{Список використаної літератури}

1. West R. Tobacco smoking: Health impact, prevalence, correlates and interventions. Psychol Health. 2017;32:1018-36.

2. Zhang L, Ren JW, Wong CC, Wu WK, Ren SX, Shen J, Chan RL and Cho CH. Effects of cigarette smoke and its active components on ulcer formation and healing in the gastrointestinal mucosa. Curr Med Chem. 2012;19:63-69.

3. Li LF, Chan RL, Lu L, Shen J, Zhang L, Wu WK, Wang L, Hu T, Li MX, Cho CH. Cigarette smoking and gastrointestinal diseases: the causal relationship and underlying molecular mechanisms (review). International journal of molecular medicine. 2014;34:372-80.

4. Park H, Park JJ, Park YM, Baik SJ, Lee HJ, Jung DH, et al.The association between Helicobacter pylori infection and the risk of advanced colorectal neoplasiamay differ according to age and cigarette smoking. $J$ Helicobacter. 2018; e12477.

5. Matsuzaki J, Suzuki H, Kobayakawa M, Inadomi JM, Takayama M, Makino K, Iwao Y, Sugino Y, Kanai T. Association of Visceral Fat Area, Smoking, and Alcohol Consumption with Reflux Esophagitis and Barrett's Esophagus in Japan. PLoSOne. 2015;10:e0133865.

6. Kanakala VV, Thomas J, Vijayaraghavan S. Alcohol Consumption and Active Helicobacter Pylori Infection. Clinical Gastroenterology and Hepatology. 2017;15.1:18.

7. Chuang Y, Wu M, Yu F, Wang Y, Lu C, Wu D, et al. Effects of alcohol consumption, cigarette smoking, and betel quid chewing on upper digestive diseases: a large cross-sectional study and meta-analysis. Oncotarget. 2017;8(44).

8. Tamura M, Matsui H, Kaneko T, et al. Alcohol is an oxidative stress or for gastric epithelial cells: detection of superoxide in living cells. J Clin Biochem Nutr 2013;53:75-80.

9. Loguercio C, Tuccillo C, Federico A et al. Alcoholic beverages and gastric epithelial cell viability: effect on oxidative stress-induced damage. J Physiol Pharmacol. 2009;60(Suppl 7):87-92.

10. Ostaff MJ, et al. Chronic Heavy Alcohol Use is Associated with Upregulated Paneth Cell Antimicrobials in Gastric Mucosa.Clinical and translational gastroenterology. 2015;6.7:103.

Стаття надійшла до редакції: 2.10.2017 p. 